\title{
Odor-Active Volatile Compounds from the Gonads of the Sea Urchin Mesocentrotus nudus in the Wild in Miyagi Prefecture, Tohoku, Japan
}

\author{
Yoichi Sato $^{1,2^{*}}$, Satomi Takagi ${ }^{3}$, Eri Inomata ${ }^{3}$, Yukio Agatsuma ${ }^{3}$ \\ ${ }^{1}$ Bio-Resources Business Development Division, Riken Food Co., Ltd., Miyauchi, Tagajyo, Miyagi, Japan \\ ${ }^{2}$ Nishina Center for Accelerator-Based Science, RIKEN, Hirosawa, Wako, Saitama, Japan \\ ${ }^{3}$ Laboratory of Marine Plant Ecology, Graduate School of Agricultural Science, Tohoku University, Aoba, Sendai, Miyagi, Japan \\ Email: *yoi_sato@rikenfood.co.jp
}

How to cite this paper: Sato, Y., Takagi, S., Inomata, E. and Agatsuma, Y. (2019) Odor-Active Volatile Compounds from the Gonads of the Sea Urchin Mesocentrotus nudus in the Wild in Miyagi Prefecture, Tohoku, Japan. Food and Nutrition Sciences, 10, 860-875.

https://doi.org/10.4236/fns.2019.107062

Received: June 27, 2019

Accepted: July 28, 2019

Published: July 31, 2019

Copyright $\odot 2019$ by author(s) and Scientific Research Publishing Inc. This work is licensed under the Creative Commons Attribution International License (CC BY 4.0).

http://creativecommons.org/licenses/by/4.0/

\begin{abstract}
Background and Aims: Mesocentrotus nudus is commercially harvested from shallow rocky bottoms in northern Japan. The gonads are targeted as an edible product. The objective of this study was to identify odor-active volatile organic compounds (VOCs) from the gonads of adult M. nudus collected at a fishing ground in Miyagi Prefecture, Tohoku, Japan. Methods and Results: Gas chromatography-mass spectrometry analysis and gas chromatography-sniffing techniques identified 42 compounds categorized as alcohols, aldehydes, aromatic hydrocarbons, esters, halomethanes, hydrocarbons, ketones, sulfur-containing compounds, and nitrogen-containing compounds. GC-sniffing analysis characterized four compounds with preferable odors of sea urchin gonads; limonene, propyl acetate, acetone, dibromochloromethane. On the other hand, the analysis characterized three compounds with unpreferable odors; methyl mercaptane, dimethyl sulfide, and s-methyl thioacetate. Several VOCs from the gonads were derived from seaweeds, terrestrial plants, and fish flesh as food because M. nudus is omnivorous. Conclusion: This is the first study to identify VOCs from edible sea urchin gonads in the wild in Japan. These VOC data comprise a typical standard in order to evaluate a higher quality of sea urchin gonads.
\end{abstract}

\section{Keywords}

Sea Urchin, Mesocentrotus nudus, Gonad Flavor, GC/MS, Sniffing Analysis

\section{Introduction}

Over the past two decades, catches of edible sea urchins have declined from 120, 
$306 \mathrm{t}$ in 1995 [1] to 69,314 t in 2016 (http://www.fao.org/fishery/en, accessed on 2 November, 2018). In particular, the catch of Chilean sea urchin Loxechinus albus, representing the largest in the world, increased to a peak at 54,740 $\mathrm{t}$ in 1995 due to the rapid expansion of fishery, followed by its full exploitation, and then declined to 30,199 t in 2016 (http://www.fao.org/fishery/en, accessed on 2 November, 2018). The catches of Strongylocentrotus droebachiensis in Maine and Mesocentrotus franciscanus along the western seaboard of North America from Baja California to Alaska dramatically declined following a peak in 1993 and 1989, respectively, due to overfishing [1].

A recognition that diminished wild stock cannot meet a strong demand has increased the amount of research on sea urchin aquaculture since the mid 1990's [2]. Among this research, some attention has been focused on the improvement of gonad qualities (texture, taste, and color) of hatchery-raised adults [3]-[10]. In contrast, research on the improvement of gonad quality of adult Mesocentrotus nudus, which densely inhabit crustose coralline "barrens" (reviewed by Agatsuma [11]), by feeding on fresh Saccharina japonica kelp, has been advancing in northern Japan [12] [13].

The free amino acids, glycine, alanine, valine, glutamic acid, and methionine, are closely associated with sea urchin gonad taste [14]. Phillips et al. [15] indicated that the umami and sweet tastes of wild Evechinus chloroticus testes and ovaries are correlated with glutamate (glutamic acid) and glycine concentrations, respectively. Takagi et al. [12] reported a marked increase in sweet tasting alanine contents of the gonads of $M$. nudus that were collected from barren and fed fresh $S$. japonica kelp for 42 days from April to June. Thereby, their sensory scores were significantly higher than those from a barren, but not significantly different from those collected from an Eisenia bicyclis kelp bed (fishing ground) in June.

In addition to taste, the flavor is an important factor of the sensory quality of sea urchin gonads [10] [16]. Phillips et al. [16] [17] assessed the gonad flavor of E. chloroticus and $S$. droebachiensis according to descriptive analysis [18] [19]. Furthermore, in parallel with the above assessment of gonad flavor, the associated components were identified and quantified using volatile analyses [20] [21]. To date, no odor active volatile compounds have been identified from the gonads of edible sea urchins in Japan. In sea urchin gonads, somatic nutritive phagocytes store extensive nutrient reserves before gametogenesis [22] [23] [24]. Hence, gonad size, color, taste, and flavor would be greatly influenced by food type because nutrient reserves are caused by food consumption.

Mesocentrotus nudus is commercially harvested in northern Japan. Together with Strongylocentrotus intermedius, it accounts for more than two-thirds of the total sea urchin landing in Japan [25]. The objective of the current study was to identify odor active volatile compounds in the gonads of adult M. nudus collected from a fishing ground in Miyagi Prefecture, Tohoku, Japan. 


\section{Methods}

\subsection{Sea Urchin Samples}

Mesocentrotus nudus were collected from a subtidal sea floor, where drift Ecklonia bicyclis kelp was concentrated, by scuba diving at the depths of $6-7 \mathrm{~m}$ off Naburi Bay $\left(38^{\circ} 53^{\prime} \mathrm{N}, 141^{\circ} 50^{\prime} \mathrm{E}\right)$, Miyagi Prefecture on July 19, 2016. Three adult sea urchins with ca. $55-70 \mathrm{~mm}$ test diameter [26], larger than a legal size (50 $\mathrm{mm}$ ) in Miyagi Prefecture, were randomly selected. The sea urchins were held in a polystyrene box filled with newspapers immersed in sea water and ice packs, and transferred to a laboratory of Riken Food Co., Ltd. in Tagajyo within 2 hours after collection. These sea urchins were dissected, and the gonads were removed and soaked three times in $5^{\circ} \mathrm{C}$ sterile seawater. Thereafter, they were drained on bleached cotton at $4^{\circ} \mathrm{C}$ for 30 minutes according to a previous study [27]. Gamete release from the gonads was not observed. The gonads were stored in a polystyrene storage container at $4^{\circ} \mathrm{C}$ until further analyses.

\subsection{Large Volume Static Headspace Sampling}

For analysis of the volatile organic compounds (VOCs) of sea urchin gonads, headspace volatile compounds were collected in a large volume static headspace system (Entech 7100A series; Entech Instruments Inc., Simi Valley, CA, USA). Sea urchin gonads were analyzed within 48 hours after collection. Each $5 \mathrm{~g}$ sample of the gonads from urchins was sealed in a $375 \mathrm{ml}$ glass jar for measurement of large volume static headspace, which was stored in an incubator (DK400, Yamato Scientific Co., Ltd., Tokyo, Japan) at $30^{\circ} \mathrm{C}$ for 10 minutes. Three batches were prepared and used for the following analysis. After incubation, $150 \mathrm{ml}$ of headspace gas was vacuum-extracted from the glass jar. The VOCs were desorbed by thermos desorption using a pre-concentrator (Entech $7100 \mathrm{~A}$ series; Entech Instruments Inc.) and applied to the gas chromatography-mass spectrometry (GC/MS) system.

\subsection{GC/MS Analysis}

Quantification of the volatile compounds was performed using an Agilent 6890 series gas chromatograph (Agilent Technologies Inc., Palo Alto, CA, USA) equipped with an Agilent 5975B mass-selective detector and a sniffing port. One half of the column flow was directed to the MS system, while the other half was directed to a heated sniffing port. The GC/MS system was equipped with a DB-WAX column $(60 \mathrm{~m} \times 0.25 \mathrm{~mm}$ i.d., $0.5 \mu \mathrm{m}$ film thickness; 122-7063; Agilent Technologies Inc.). The GC operation conditions comprised an injector temperature of $250^{\circ} \mathrm{C}$. Analyses were carried out using helium as the carrier gas at an average flow rate of $27 \mathrm{~cm} \cdot \mathrm{sec}^{-1}$ with the following temperature program: $40^{\circ} \mathrm{C}$ for $5 \mathrm{~min}$, increased at $5^{\circ} \mathrm{C} \cdot \mathrm{min}^{-1}$ to $240^{\circ} \mathrm{C}$, followed by a final 5 minutes hold at $240^{\circ} \mathrm{C}$.

Mass spectrometry was carried out in scan mode using an electron ionization voltage of $70 \mathrm{eV}$ and a scan range from $\mathrm{m} / \mathrm{z} 10$ to 300 every 1.58 every sec. Anal- 
ysis of VOCs was performed using Powered Pro software (Willey 11N17main, Agilent Technologies Inc.). The relative amounts of VOCs were calculated based on the peak areas in the chromatograms.

\subsection{Gas Chromatography-Olfactometry Analysis}

The type and composition ratio of VOCs can be revealed by GC/MS analysis; however, since its peak is large, it does not necessarily have a large contribution to sample scent. Thereby, gas chromatography-olfactometry techniques were conducted in the present study; these can obtain information on the quality and strength of odors by human sniffing the smell of ingredients introduced from GC [28]. One half of the column flow was directed to a heated sniffing port (ODP2 Oflactory Detection Port, Gerstel GmbH \& Co.KG, Mülheim an der Ruhr, Germany). To the sniffing port, humidified air $(50 \%-75 \%$ relative humidity) was carried at $1.02 \mathrm{ml} \cdot \mathrm{min}^{-1}$ in order to prevent the drying out of the nose, causing considerable discomfort for assessors and degradation of sensitivity [29] [30]. The panelist recorded the retention time and the description of the aroma compounds [16] [31]. Each gonad from three sea urchins was used for the sniffing analysis. When a volatile compound was detected in all gonads, this analysis was determined to be a declared aroma compound related to sea urchin gonads.

\section{Results and Discussion}

The VOCs of the gonads from three sea urchins collected in Naburi Bay, Miyagi Prefecture were analyzed by GC/MS. Typical total ion chromatograms of VOCs from sea urchin gonads are shown in Figure 1. A total of 42 compounds were identified from all gonads. These compounds can be categorized into the following chemical families; alcohols (5), aldehydes (8), aromatic ring-structured compounds (7), esters (5), halomethanes (3), hydrocarbons (5), ketones (5), and others (4; methyl mercaptan [MM], dimethyl sulfide [DMS], acetonitrile, and Bis-(methylthio)-methane) (Table 1). Among them, 22 compounds were identified by GC-sniffing analyses (Table 2). VOCs were detected from fresh and canned gonads of Paracentrotus lividus collected from Galicia in Spain [32], and from testes and ovaries of Evechinus chloroticus collected from the North and South Islands of New Zealand [21]. The 13 compounds of these two previous studies were also detected in the present study (Table 1).

\subsection{Alcohols}

The five compounds of saturated alcohols: methanol, 2-propanol, ethanol, 2-butanol, and 2-ethyl hexanol were detected in the present study. Methanol and 2-ethyl hexanol were also found in the gonads of E. chloroticus as possible compounds [20]. Unsaturated alcohols could significantly contribute to odor due to their relatively low odor threshold value [33]. On the other hand, saturated alcohols could have insignificant contributions to odor due to their rela 


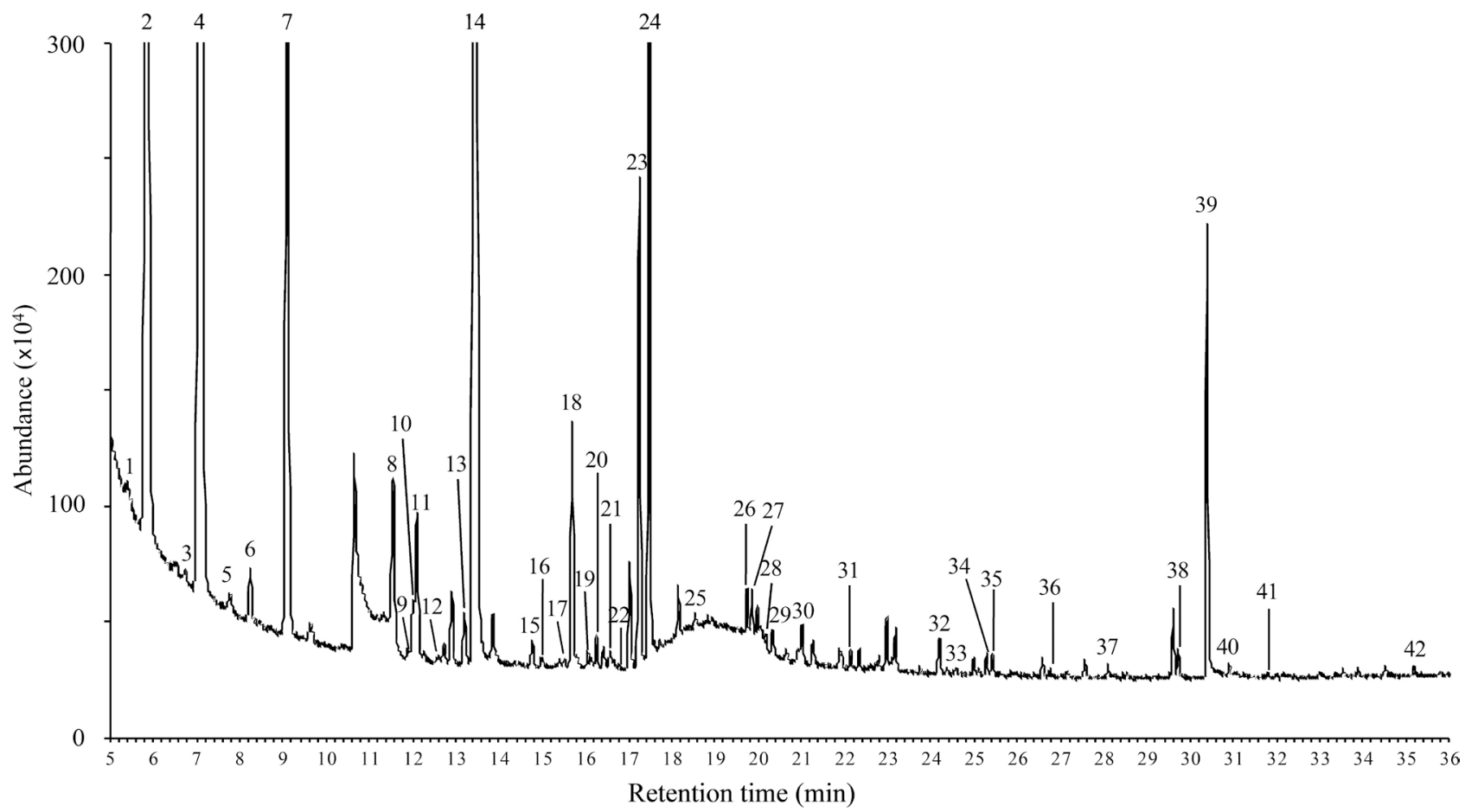

Figure 1. Chromatograms of volatile organic compounds (VOCs) in the gonads of adult Mesocentrotus nudus by gas chromatography-mass spectrometry (GC/MS). Compounds were identified by peak numbers as shown in Table 1.

Table 1. Volatile composition of volatile organic compounds (VOCs) in gonads of $\mathrm{Me}$ socentrotus nudus.

\begin{tabular}{|c|c|c|c|}
\hline No. & Volatile compounds & $\begin{array}{l}\text { Retention time } \\
\text { (min) }\end{array}$ & $\begin{array}{c}\text { Relative content } \\
\text { (\%) }\end{array}$ \\
\hline \multicolumn{4}{|c|}{ Alcohols (5) } \\
\hline 10 & Methanol $^{\mathrm{a}}$ & 12.05 & 0.42 \\
\hline 13 & 2-Propanol & 13.21 & 0.41 \\
\hline 14 & Ethanol & 13.46 & 47.06 \\
\hline 21 & 2-Butanol & 16.57 & 0.05 \\
\hline 39 & 2-Ethyl haxanol & 30.41 & 2.45 \\
\hline \multicolumn{4}{|c|}{ Aldehydes (8) } \\
\hline 2 & Acetaldehyde $^{\mathrm{a}}$ & 5.87 & 7.13 \\
\hline 3 & Dimethoxy methane & 6.74 & 0.11 \\
\hline 6 & Propanal $^{\mathrm{a}}$ & 8.24 & 0.48 \\
\hline 9 & Acetal & 11.78 & 0.01 \\
\hline 12 & 3-Methyl butanal ${ }^{\mathrm{a}}$ & 12.75 & 0.06 \\
\hline 37 & Nonanal $^{\mathrm{b}}$ & 28.12 & 0.07 \\
\hline 40 & Decanal $^{\mathrm{b}}$ & 30.92 & 0.11 \\
\hline 41 & Benzaldehyde $\mathrm{e}^{\mathrm{a}, \mathrm{b}}$ & 32.01 & 0.01 \\
\hline \multicolumn{4}{|c|}{ Aromatic ring-structured compounds (7) } \\
\hline 5 & Methyl cyclohexane & 7.79 & 0.20 \\
\hline
\end{tabular}




\section{Continued}

\begin{tabular}{|c|c|c|c|}
\hline 23 & Toluene $^{\mathrm{a}}$ & 17.26 & 3.15 \\
\hline 27 & Ethyl benzene $^{\mathrm{b}}$ & 19.87 & 0.19 \\
\hline 29 & Xylene $^{\mathrm{a}}$ & 20.34 & 0.17 \\
\hline 32 & Styrene & 24.23 & 0.28 \\
\hline 36 & Trimethyl benzene & 26.77 & 0.04 \\
\hline 38 & Dichlorobenzene $\mathrm{e}^{\mathrm{b}}$ & 29.74 & 0.17 \\
\hline \multicolumn{4}{|c|}{ Esters (5) } \\
\hline 8 & Ethyl acetate & 11.56 & 0.81 \\
\hline 15 & Propyl acetate & 14.80 & 0.19 \\
\hline 24 & S-Methyl thioacetate & 17.48 & 2.95 \\
\hline 26 & S-Methyl propanethioate & 19.75 & 0.22 \\
\hline 28 & S-Methyl thiobutyrate & 20.18 & 0.07 \\
\hline \multicolumn{4}{|c|}{ Halomethanes (3) } \\
\hline 20 & Chloroform & 16.26 & 0.23 \\
\hline 30 & Dibromomethane & 21.02 & 0.10 \\
\hline 34 & Dibromochloromethane & 25.29 & 0.12 \\
\hline \multicolumn{4}{|c|}{ Hydrocarbons (5) } \\
\hline 17 & Decane & 15.53 & 0.08 \\
\hline 22 & $\alpha$-Pinene & 16.68 & 0.02 \\
\hline 25 & Undecane & 18.56 & 0.08 \\
\hline 31 & Limonene $^{\mathrm{a}, \mathrm{b}}$ & 22.15 & 0.13 \\
\hline 33 & Tridecane & 24.61 & 0.02 \\
\hline \multicolumn{4}{|c|}{ Ketones (5) } \\
\hline 7 & Acetone & 9.12 & 6.15 \\
\hline 11 & 2-Butanone & 12.13 & 0.80 \\
\hline 16 & 2-Pentanone & 15.00 & 0.09 \\
\hline 19 & 4-Methyl-2-pentanone & 16.06 & 0.10 \\
\hline 42 & Acetophenone & 35.20 & 0.08 \\
\hline \multicolumn{4}{|c|}{ Other compounds (4) } \\
\hline 1 & Methyl mercaptane & 5.42 & 0.21 \\
\hline 4 & Dimethyl sulfide $^{a}$ & 7.09 & 23.19 \\
\hline 18 & Acetonitrile & 15.72 & 1.70 \\
\hline 35 & Bis-(methylthio)-methane & 25.42 & 0.12 \\
\hline
\end{tabular}

a) Niimi et al. (2010), b) De Quiros et al. (2001). 
Table 2. Volatile compounds of Mesocentrotus nudus with their odour descriptions.

\begin{tabular}{|c|c|c|c|}
\hline No. & Compounds & Retention time (min) & Odour description \\
\hline 1 & Methyl mercaptane & 5.42 & Eggs, Fish \\
\hline 2 & Acetaldehyde & 5.87 & Metalic \\
\hline 4 & Dimethyl sulfide & 7.09 & Marine, Fish \\
\hline 6 & Propanal & 8.24 & Heavy, Metaric \\
\hline 7 & Acetone & 9.12 & Sweet \\
\hline 14 & 2-Propanol & 13.21 & Kelp, Dry \\
\hline 16 & Propyl actate & 14.80 & Sweet, Sugar \\
\hline 18 & Trichloroethene & 15.39 & Dusty \\
\hline 23 & 2-Butanol & 16.57 & Fish, Marine \\
\hline 24 & $\alpha$-Pinene & 16.68 & Burning \\
\hline 26 & S-Methyl thioacetate & 17.48 & Sulfer, Fishly, Fish oil, Ammonia \\
\hline 28 & S-Methyl propanethioate & 19.75 & Ozone \\
\hline 29 & Ethyl benzene & 19.87 & Fish oil \\
\hline 30 & S-Methyl thiobutyrate & 20.18 & Metalic \\
\hline 33 & Limonene & 22.15 & Floral, Binegar \\
\hline 34 & Styrene & 24.23 & Heavy, Metalic \\
\hline 35 & Tridecane & 24.61 & Ozone \\
\hline 36 & Dibromochloromethane & 25.29 & Bitter, Sweet \\
\hline 37 & Bis(methyl thio)methane & 25.42 & Ozone, Sulfer \\
\hline 38 & Trimethyl benzene & 26.77 & Bitter, Sweet \\
\hline 39 & Nonanal & 28.12 & Dusty, Ozone \\
\hline 42 & Decanal & 30.92 & Vinegar, Sweet, Armond \\
\hline
\end{tabular}

tively high odor threshold value [34]. Therefore, the contributions of the five compounds of sa-turated alcohols to the aroma of sea urchin gonads might be inconsiderable. Ethanol was the highest value of relative content.

\subsection{Aldehydes}

The eight compounds of aldehydes: acetaldehyde, dimethoxy methane, propanal, acetal, 3-methyl butanal, nonanal, decanal, and benzaldehyde were identified from the gonads of $M$. nudus in the present study. Of them, six aldehydes: acetaldehyde, propanal, 3-methyl butanal, nonanal, decanal, and benzaldehyde were common in the gonads of P. lividus [32] and E. chloroticus [21]. Aldehydes are produced by oxidative degradation of fatty acids, and they have been detected in many fish and shellfish including crabs (Chionoecetes japonicus) [35], scallops (Mizuhopecten yessoensis) [36], sea bream (Sparus aurata) [37], and Ayu fish (Plecoglossus altivelis) [38]. Aldehydes could have significant contributions to odor in various species due to their relatively low odor threshold values [39] 
[40]. Furthermore, nonanal and benzaldehyde were detected in three kombu kelps (Saccharina japonica, S. japonica var. ochotensis, and S. angustata) [41] and two Rhodophytes (Pterocladiella capillacea and Osmundaria obtusiloba) [42]. Nonanal, benzaldehyde, and decanal have been detected in Ulva pertusa [43], suggesting these compounds originated from seaweeds, which are principal foods for M. nudus. Among these compounds, benzaldehyde has a pleasant almond nutty and stone fruit aroma [44], suggesting that this compound may have a desirable effect on the aroma of sea urchin gonads [32]

\subsection{Aromatic Hydrocarbons}

The seven compounds of aromatic hydrocarbons: methyl cyclohexane, toluene, ethyl benzene, xylene, styrene, trimethyl benzene, and dichlorobenzene were identified. These compounds are known as the derivatives from thermal decomposition of sugars and amino acids [45] [46], and oxidation degradation of carotenoids [32].

Styrene and ethyl benzene are related to the xenobiotic-metabolizing enzymes of Strongylocentrotus purpuratus [47], and ethyl benzene has been tentatively identified from P. lividus [32] and E. chloroticus [20]. The present study findings suggest the existence of the same enzyme from the gonads of M. nudus. Additionally, GC sniffing-analysis indicated that ethylbenzene had a scent comparable to "fish oil", which is reminiscent of the pleasant aroma of fresh sea urchin gonads (Table 2).

\subsection{Esters}

The five compounds of esters: ethyl acetate, propyl acetate, S-methyl thioacetate, S-methyl propanethioate, and S-methyl thiobutyrate were identified. Although esters have rarely been detected in edible fishes and shellfishes, these compounds are important contributors to the sweet aroma of various fruits [48]. Therefore, these ester compounds possibly affect the sweet aroma of M. nudus gonads [12].

\subsection{Halomethanes}

Of the VOCs, two halomethane compounds: Dibromomethane and dibromochloromethane were first detected in the present study. In the past, these compounds were not found in sea urchin gonads and other edible shellfish. Crustose and articulated coralline algae (Rhodophyta) produce halomethane compounds [49] [50], among which dibromomethane is known as an inducer of settlement and metamorphosis of M. nudus larvae [51] [52]. Halomethane compounds detected in the present study are derived from crustose and/or articulated coralline algae ingested as food sources [53] [54].

\subsection{Hydrocarbons}

The five compounds of hydrocarbons: decane, $\alpha$-pinene, undecane, limonene, and tridecane were identified in the gonads. Hydrocarbons constitute the most 
important family of VOCs in the gonads of $P$. lividus [32], although the large amounts of these VOCs did not appear to contribute significantly to flavor due to their high flavor thresholds [55]. These compounds are derived from the decarboxylation reaction of fatty acid and thermal decomposition of carotenoids [56] [57]. Of them, limonene has a flavor comparable to sweet citrus with a freshness. This hydrocarbon has been detected in other sea urchin species [21] [32], fish (Notropsis atherinoides) [39], prawn (Pleoticus muelleri) [58], scallop (Placopecten magellanicus) [57], and the seaweeds U. pertusa [43] and S. japonica, $S$. japonica var. ochotensis, and $S$. angustata [41]. This compound can accumulate in the gonads of $M$. nudus through consumption of seaweeds. Alpha-pinene is a principle VOC derived from coniferous trees such as pine [59]; it is rarely detected in sea urchins, fishes, and other shellfish. Mesocentrotus nudus consume seaweeds and also other organisms [11]. Coniferous leaves and branches that have been transferred from land to the seabed would be consumed and accumulated in the gonads.

\subsection{Ketones}

The five compounds of ketones, acetone, 2-butanone, 2-pentanone, 4-methyl2pentaone, and acetophenone, were detected in the gonads. Ketones are produced by oxidative degradation of fatty acid. They have been detected from various edible fishes and shellfish species, comparable to aldehydes [36] [55]. The compound 4-methyl-2-pentanone was found in canned products of sea urchin gonads of P. lividus [32]. Detection of this compound in the raw urchin gonads inferred that the unsaturated fatty acid was quickly oxidized and decomposed even during cold storage.

\subsection{Other Compounds}

Four other compounds, DMS, MM, Bis-(methylthio)-methane, and acetonitrile were detected. DMS, MM, and Bis-(methylthio)-methane were sulfur-containing. These were derived from the decomposition of sulfur-containing proteins in vivo and might have a strong effect on the overall flavor due to their low threshold [60]. Sulfur and fish smells were noted at the peak of MM according to gas chromatography-olfactometry analyses in the present study. The relative content of DMS showed the second highest value among all the compounds. DMS has been detected from several edible fishes and shellfish including the gonads of $E$. chloroticus [21], red queen crab (Chionoecetes japonicus) [35], scallops (Mizuhopecten yessoensis) [36], and Nile tilapia (Oreochromis niloticus) [61]. These sulfur-containing compounds contributed to odors of "sulfur and rubber" in the sea fig (Microcosmus vulgaris) [62] and an odor of "sulfur" in the oyster (Crassostrea gigas) [63]. These compounds detected in the present study appeared to be affected not only by in vivo metabolism, but also by direct ingestion of dead fish flesh [64], followed by digestion and absorption as sulfur-containing proteins. Additionally, DMS is regarded as a typical compound produced by cutting 
U. pertusa [43] and has been identified as a typical VOC of Ulva species [65]. Therefore, these sulfur-containing compounds from the sea urchin gonads might have been also derived from Ulva species.

\subsection{Gonad VOCs}

The number of VOCs detected from M. nudus gonads in the present study was larger than that from the gonads of other sea urchin species observed in previous studies [21] [32]. The compounds detected in the GC-sniffing analyses included some that had odors comparable to those of the sea urchin gonads such as limonene (floral, vinegar), propyl acetate (sweet, sugar), acetone (sweet), and dibromochloromethane (bitter, sweet). These compounds constitute mainly preferable flavor of sea urchin gonads. On the other hand, MM (egg, fish), DMS (marine, fish), and s-methyl thioacetate (sulfur) were noted as unpreferable odors (Table 2). The relative content of these compounds was not necessarily large (Table 1), thereby the sniffing analysis is an important method for evaluating the contribution to the flavor of sea urchin gonads. Since odor is an important factor in determining the quality of sea urchin gonads at the market, the balance of these VOCs would influence their evaluation. VOCs from gonads before gametogenesis are derived from various foods such as seaweeds, terrestrial plants, and fish flesh because M. nudus is an omnivore [11]. In fish aquaculture, feed odors reflect their meat [66]. Miyasaki and Kitamura [61] used feeds prepared with feed oil, with many aldehydes and DMS (experimental), and soybean oil with low compounds (control) fed to Nile tilapia (Oreochromis niloticus). As a result, the flesh and inward organs of individuals fed the experimental feed had a larger number of VOCs and area of GC/MS analysis than the control group. The sensory evaluation confirmed an unpleasant odor. Phillips et al. [16] reported that the gonads of E. chloroticus fed a diet with high glutamate and glycine contents had a sweeter taste than those fed a diet with high valine and methionine contents, which had marine and sulfur odors. These studies indicated a possibility that preparing feed, of which unpleasant odor compounds were suppressed, improved sea urchin gonad flavor. In focusing on the VOCs of sea urchin gonads, improvement of gonad flavor, in addition to gonad size, texture, color, and taste, would require high-level techniques of sea urchin aquaculture. To the best of the authors' knowledge, this study was the first to identify VOCs from edible sea urchin gonads in a kelp bed (fishing ground) in Japan. The VOC data obtained comprise a typical standard that can contribute to the evaluation of higher quality sea urchin gonads.

\section{Acknowledgements}

We sincerely thank Tokumi Goshima of the Ogatsu Branch of the Miyagi Fisheries Cooperative Association for sea urchin collection. We are also very grateful to Atsuko Kokubun of Riken Vitamin Co., Ltd. for GC/MS analyses. 


\section{Conflicts of Interest}

The authors declare no conflicts of interest regarding the publication of this paper.

\section{References}

[1] Andrew, N.L., Agatsuma, Y., Ballesteros, E., Bazhin, A.G., Creaser, E.P., Barnes, D.K.S., Botsford, L.W., Bradbury, A., Campbell, A., Dixon, J.D., Einarsson, S., Gerring, P.K., Hebert, K., Hunter, M., Hur, S.B., Johnson, C.R., Junio-Meñez Kalvass, P., Miller, R.J., Moreno, C.A., Palleiro, J.S., Rivas, D., Robinson, S.M.L., Schroeter, S.C., Steneck, R.S., Vadas, R.L., Woodby, D.A., et al. (2002) Status and Management of World Sea Urchin Fisheries. Oceanography and Marine Biology, 40, 343-425.

[2] Pearce, C.M. (2010) Introduction. Sea-Urchin Aquaculture. Bulletin of Aquaculture Association of Canada, 108, 1.

[3] Goebel, N. and Barker, M.F. (1998) Artificial Diets Supplemented with Carotenoid Pigments as Feeds for Sea Urchins. In: Mooi, R. and Telford, M., Eds., Echinoderms. San Francisco, Balkema, Rotterdam, 667-672.

[4] Kelly, M.S., Brodie, C.C. and McKenzie, J.D. (1998) Somatic and Gonadal Growth of the Sea Urchin Psammechinus miliaris (Gmelin) Maintained in Polyculture with the Atlantic Salmon. Journal of Shellfish Research, 17, 1557-1562.

[5] McLaughlin, G. and Kelly, M.S. (2001) Effect of Artificial Diets Containing Carotenoid-Rich Macroalgae on Gonad Growth and Color in the Sea Urchin Psammechinus miliaris (Gmelin). Journal of Shellfish Research, 20, 377-382.

[6] Pearce, C.M., Daggett, T.L. and Robinson, S.M. (2002) Effect of Binder Type and Concentration on Prepared Feed Stability and Gonad Yield and Quality of the Green Sea Urchin, Strongylocentrotus droebachiensis. Aquaculture, 205, 301-323. https://doi.org/10.1016/S0044-8486(01)00685-8

[7] Pearce, C.M., Daggett, T.L. and Robinson, S.M.C. (2002) Effect of Protein Source Ratio and Protein Concentration in Prepared Diets on Gonad Yield and Quality of the Green Sea Urchin, Strongylocentrotus droebachiensis. Aquaculture, 214, 307-332. https://doi.org/10.1016/S0044-8486(02)00041-8

[8] Pearce, C.M., Daggett, T.L. and Robinson, S.M.C. (2002) Optimizing Prepared Feed Ration for Gonad Production of the Green Sea Urchin Strongylocentrotus droebachiensis. Journal of World Aquaculture Society, 33, 268-276. https://doi.org/10.1111/j.1749-7345.2002.tb00503.x

[9] Robinson, S.M.C., Dastell, J.D. and Kennedy, E.J. (2002) Developing Suitable Colour in the Gonads of Cultured Green Sea Urchins (Strongylocentrotus droebachiensis). Aquaculture, 206, 289-303. https://doi.org/10.1016/S0044-8486(01)00723-2

[10] McBride, S.C., Price, R.J., Tom, P.D., Lawrence, J.M. and Lawrence, A.L. (2004) Comparison of Gonad Quality Factors: Color, Hardness and Resilience, of Strongylocentrotus franciscanus between Sea Urchins Fed Prepared Feed or Algal Diets and Sea Urchins Harvested from the Northern California Fishery. Aquaculture, 233, 405-422. https://doi.org/10.1016/j.aquaculture.2003.10.014

[11] Agatsuma, Y. (2013) Strongylocentrotus nudus. In: Lawrence, J.M., Ed., Sea Urchins: Biology and Ecology, 3rd Edition, Academic Press, San Diego, CA, 449-460. https://doi.org/10.1016/B978-0-12-396491-5.00029-0

[12] Takagi, S., Murata, Y., Inomata, E., Endo, H., Aoki, M.N. and Agatsuma, Y. (2017) Improvement of Gonad Quality of the Sea Urchin Mesocentrotus nudus Fed the 
Kelp Saccharina japonica during Offshore Cage Culture. Aquaculture, 477, 50-61. https://doi.org/10.1016/j.aquaculture.2017.04.033

[13] Takagi, S., Murata, Y., Inomata, E., Endo, H., Aoki, M.N. and Agatsuma, Y. (2018) Dietary Effect of Kelp (Saccharina japonica) on Gonad Quantity and Quality in Sea Urchin (Mesocentrotus nudus) Collected from a Barren Before the Fishing Season. Journal of Shellfish Research, 37, 659-669. https://doi.org/10.2983/035.037.0318

[14] Komata, Y. (1964) Studies of the Extractives of "Uni” IV. Taste of Each Component in the Extractives. Bulletin of Japanese Society of Fisheries Science, 30, 749-756. (in Japanese with English Abstract)

[15] Phillips, K., Hamid, N., Silcock, P., Sedwell, M.A., Barker, M., Weaver, A., Then, S., Delahunty, C. and Bremer, P. (2010) Effect of Manufactured Diets on the Yield, Biochemical Composition and Sensory Quality of Evechinus chloroticus Sea Urchin Gonads. Aquaculture, 308, 49-59. https://doi.org/10.1016/j.aquaculture.2010.07.030

[16] Phillips, K., Bremer, P., Silcock, P., Hamid, N., Delahunty, C., Barker, M. and Kissick, J. (2009) Effect of Gender, Diet and Storage Time on the Physical Properties and Sensory Quality of Sea Urchin (Evechinus chloroticus) Gonads. Aquaculture, 288, 205-215. https://doi.org/10.1016/j.aquaculture.2008.11.026

[17] Phillips, K., Hamid, N., Silcock, P., Delahunty, C., Barker, M. and Bremer, P. (2010) Effect of Season on the Sensory Quality of Sea Urchin (Evechinus chloroticus) Roe. Journal of Food Science, 75, S20-S30. https://doi.org/10.1111/j.1750-3841.2009.01388.x

[18] Muñoz, A.M. and Civille, G.V. (1998) Universal, Product and Attribute Specific Scaling and the Development of Common Lexicons in Descriptive Analysis. Journal of Sensory Studies, 13, 57-75. https://doi.org/10.1111/j.1745-459X.1998.tb00075.x

[19] Siikavopio, S.L., Dale, T. and Carlehog, M. (2007) Sensory Quality of Gonads from the Green Sea Urchin, Strongylocentrotus droebachiensis, Fed Different Diets. Journal of Shellfish Research, 26, 637-644. https://doi.org/10.2983/0730-8000(2007)26[637:SQOGFT]2.0.CO;2

[20] Phillips, K., Niimi, J., Hamid, N., Silcock, P., Delahunty, C., Barker, M., Sewell, M. and Bremer, P. (2010) Sensory and Volatile Analysis of Sea Urchin Roe from Different Geographical Regions in New Zealand. LWT_Food Science and Technology, 43, 202-213. https://doi.org/10.1016/j.lwt.2009.08.008

[21] Niimi, J., Leus, M., Silcock, P., Hamid, N. and Bremer, P. (2010) Characterisation of Odor Active Volatile Compounds of New Zealand Sea Urchin (Evechinus chloroticus) Roe Using Gas Chromatography-Olfactometry-Finger Span Cross Modality (GC-OFSCM) Method. Food Chemistry, 121, 601-607. https://doi.org/10.1016/j.foodchem.2009.12.071

[22] Holland, N.D. and Holland, L.Z. (1969) Annual Cycles in Germinal and Non-Germinal Cell Populations in the Gonads of the Sea Urchin Psammechinus microtuberculatus. Pubblicazioni della Stazione Zoologica di Napoli, 37, 394-404.

[23] Walker, C.W., Harrington, L.M., Lesser, M.P. and Fagerberg, W.R. (2005) Nutritive Phagocyte Incubation Chambers Provide a Structural and Nutritive Microenvironment for Germ Cells of Strongylocentrotus droebachiensis, the Green Sea Urchin. The Biological Bulletin, 209, 31-48. https://doi.org/10.2307/3593140

[24] Walker, C.W., Unuma, T. and Lesser, M.P. (2013) Sea Urchin Gametogenesis-Structural, Functional and Molecular/Genomic Biology. In: In: Lawrence, J.M., Ed., Sea Urchins. Biology and Ecology, 3rd Edition, Elsevier B.V., Amsterdam, 25-43. https://doi.org/10.1016/B978-0-12-396491-5.00003-4

[25] Unuma, T. (2015) Introduction: Sea Urchin Fisheries in Japan. Sea Urchin Aqua- 
culture in Japan. In: Brown, N.P. and Eddy, S.D., Eds., Echinoderm Aquaculture, Wiley Blackwell, Hoboken, NJ, 77-85. https://doi.org/10.1002/9781119005810.ch5

[26] Fuji, A. (1960) Studies on the Biology of the Sea Urchin. II. Size at First Maturity and Sexuality of Two Sea Urchins, Strongylocentrotus nudus and S. intermedius. Bulletin of Faculty of Fisheries Hokkaido University, 11, 43-48.

[27] Kinoshita, Y., Yoshioka, T., Miyazaki, S., Kato, S. and Konno, K. (2009) Storage of Sea Urchin Gonad in Oxygenated Sea Water. Nippon Suisan Gakkaishi, 75, 237-243. (in Japanese with English Abstract)

[28] Fuller, G.H., Steltenkamp, R. and Tisserand, G.A. (1964) The Gas Chromatograph with Human Sensor: Perfumer Model. Annuals of the New York Academy of Science, 116, 711-724. https://doi.org/10.1111/j.1749-6632.1964.tb45106.x

[29] Dravnieks, A. and O'Donnell, A. (1971) Principles and Some Techniques of High-Resolution Headspace Analysis. Journal of Agricultural Food Chemistry, 19, 1049-1056. https://doi.org/10.1021/jf60178a002

[30] Delahunty, C.M., Eyres, G. and Dufour, J.P. (2006) Gas Chromatography-Olfactometry. Journal of Separation Science, 29, 2107-2125.

https://doi.org/10.1002/jssc.200500509

[31] McDonnell, E., Hulin-Bertaud, S., Sheehan, E.M. and Delahunty, C.M. (2001) Development and Learning Process of a Sensory Vocabulary for the Odor Evaluation of Selected Distilled Beverages Using Descriptive Analysis. Journal of Sensory Studies, 16, 425-445. https://doi.org/10.1111/j.1745-459X.2001.tb00311.x

[32] De Quirós, A.R.B., López-Hernández, J., González-Castro, M.J. de la Cruz-García, C. and Simal-Lozano, J. (2001) Comparison of Volatile Components in Fresh and Canned Sea Urchin (Paracentrotus lividus, Lamarck) Gonads by GC-MS Using Dynamic Headspace Sampling and Microwave Desorption. European Food Research and Technology, 212, 643-647. https://doi.org/10.1007/s002170100315

[33] Siek, T.J., Albin, I.A., Sather, L.A. and Lindsay, R.C. (1971) Comparison of Flavor Thresholds of Aliphatic Lactones with Those of Fatty Acids, Esters, Aldehydes, Alcohols, and Ketones. Journal of Dairy Science, 54, 1-4. https://doi.org/10.3168/jds.S0022-0302(71)85770-3

[34] Peralta, R., Shimoda, M. and Osajima, Y. (1996) Further Identification of Volatile Compounds in Fish Sauce. Journal of Agricultural Food Chemistry, 44, 3606-3610. https://doi.org/10.1021/jf9603036

[35] Yanohara, T. and Kodani, Y. (2012) Evaluation of Chionoecetes japonicus Meat Quality Using Volatile Analysis. Tottori Institute of Industrial Technology, 15, 58-61. (in Japanese)

[36] Narita, M., Furuta, T., Miyazaki, A., Sato, A., Shimizu, S., Ebitani, K. and Sasaki, S. (2017) Sensory Evaluation and Volatile-Compound Analysis of Scallops during Refrigerated Storage at $5^{\circ} \mathrm{C}$. Japanese Society for Food Science and Technology, 64, 66-73. (In Japanese with English Abstract)

[37] Grigorakis, K., Taylor, K.D.A. and Alexis, M.N. (2003) Organoleptic and Volatile Aroma Compounds Comparison of Wild and Cultured Gilthead Sea Bream (Sparus aurata): Sensory Differences and Possible Chemical Basis. Aquaculture, 225, 109-119. https://doi.org/10.1016/S0044-8486(03)00283-7

[38] Hirano, T., Zhang, C.H., Morishita, A., Suzuki, T. and Shirai, T. (1992) Identification of Volatile Compounds in Ayu Fish and Its Feeds. Nippon Suisan Gakkaishi, 58, 547-557.

[39] Josephson, D.B., Lindsay, R.C. and Stuiber, D.A. (1984) Biogenesis of Lipid-Derived Volatile Aroma Compounds in the Emerald Shiner (Notropis atherinoides). Journal 
of Agricultural Food Chemistry, 32, 1347-1352. https://doi.org/10.1021/jf00126a032

[40] Turchini, G., Moretti, V.M., Mentasti, T., Orban, E. and Valfrè, F. (2007) Effects of Dietary Lipid Source on Fillet Chemical Composition, Flavour Volatile Compounds and Sensory Characteristics in the Freshwater Fish Tench (Tinca tinca L.). Food Chemistry, 102, 1144-1155. https://doi.org/10.1016/j.foodchem.2006.07.003

[41] Takahashi, H., Sumitani, H., Inada, Y. and Mori, D. (2002) Identification of Volatile Compounds of Kombu (Laminaria spp.) and Their Odor Description. Journal of the Japanese Society for Food Science and Technology, 49, 228-237. (in Japanese with English Abstract)

[42] Alencar, D.B., Diniz, J.C., Rocha, S.A.S., Pires-Cavalcante, K.M.S., Freitas, J.O., Nagano, C.S., Sampaio, A.H. and Saker-Sampaio, S. (2017) Chemical Composition of Volatile Compounds in Two Red Seaweeds, Pterocladiella capillacea and Osmundaria obtusiloba, Using Static Headspace Gas Chromatography Mass Spectrometry. Journal of Applied Phycology, 29, 1571-1576.

https://doi.org/10.1007/s10811-016-1020-3

[43] Tamura, H., Nakamoto, H., Yang, R.H. and Sugisawa, H. (1995) Characteristic Aroma Compounds in Green Algae (Ulva pertusa) Volatiles. Nippon Shokuhin Kagaku Kogaku Kaishi, 42, 887-891. (In Japanese with English Abstract)

[44] Narain, N., Hsieh, T.C.Y. and Johnson, C.E. (1990) Dynamic Headspace Concentration and Gas Chromatography of Volatile Flavor Components in Peach. Journal of Food Science, 55, 1303-1307. https://doi.org/10.1111/j.1365-2621.1990.tb03921.x

[45] Keyhani, A. and Yalayan, V.A. (1996) Pyrolysis/GC/MS Analysis of N-(1-Deoxy-DFructos-1-Yl)-L-Phenylalanine: Identification of Novel Pyridine and Naphthalene Derivatives. Journal of Agricultural Food Chemistry, 44, 223-229. https://doi.org/10.1021/jf950418u

[46] Chung, H.Y., Yung, I.K.S., Ma, W.C.J. and Kim, J.-S. (2002) Analysis of Volatile Components in Frozen and Dried Scallops (Patinopecten yessoensis) by Gas Chromatography/Mass Spectrometry. Food Research International, 35, 43-53. https://doi.org/10.1016/S0963-9969(01)00107-7

[47] Goldstone, J.V., Hamdou, A., Cole, B.J., Howard-Ashby, M., Nebert, D.W., Scally, M., Dean, M., Epel, D., Hahn, M.E. and Stegeman, J.J. (2006) The Chemical Defensome: Environmental Sensing and Response Genes in the Strongylocentrotus purpuratus Genome. Developmental Biology, 300, 366-384. https://doi.org/10.1016/j.ydbio.2006.08.066

[48] Shalit, M., Katzir, N., Tadmor, Y., Larkov, O., Burger, Y., Shalekhet, F., Lastochkin, E., Ravid, U., Amar, O., Edelstein, M., Karchi, Z. and Lewinsohn, E. (2001) Acetyl-CoA: Alcohol Acetyltransferase Activity and Aroma Formation in Ripening Melon Fruits. Journal of Agricultural Food Chemistry, 49, 794-799. https://doi.org/10.1021/jf001075p

[49] Fenical, W. (1975) Halogenation in the Rhodophyta a Review. Journal of Phycology, 11, 245-259. https://doi.org/10.1111/j.1529-8817.1975.tb02775.x

[50] Itoh, N. and Shinya, M. (1994) Seasonal Evolution of Bromomethanes from Coralline Algae (Corallinaceae) and Its Effect on Atmospheric Zone. Marine Chemistry, 45, 95-103. https://doi.org/10.1016/0304-4203(94)90094-9

[51] Taniguchi, K., Kurata, K., Maruzoi, T. and Suzuki, M. (1994) Dibromomethane, a Chemical Inducer of Larval Settlement and Metamorphosis of the Sea Urchin Strongylocentrotus nudus. Fisheries Science, 60, 795-796. https://doi.org/10.2331/fishsci.60.795

[52] Agatsuma, Y., Seki, T., Kurata, K. and Taniguchi, K. (2006) Instantaneous Effect of 
Dibromomethane on Metamorphosis of Larvae of the Sea Urchins Strongylocentrotus nudus and Strongylocentrotus intermedius. Aquaculture, 251, 549-557. https://doi.org/10.1016/j.aquaculture.2005.05.043

[53] Endo, H., Nakabayashi, N., Agatsuma, Y. and Taniguchi, K. (2007) Food of the Sea Urchins Strongylocentrotus nudus and Hemicentrotus pulcherrimus Associated with Vertical Distributions in Fucoid Beds and Crustose Coralline Flats in Northern Honshu, Japan. Marine Ecology Progress Series, 352, 125-135. https://doi.org/10.3354/meps07121

[54] Sano, M., Omori, M., Taniguchi, K. and Seki, T. (2001) Age Distribution of the Sea Urchin Strongylocentrotus nudus (A. Agassiz) in Relation to Algal Zonation in a Rocky Coastal Area on Oshika Peninsula, Northern Japan. Fisheries Science, 67, 628-639.

[55] Cha, Y.J., Cadwallader, K.R. and Baek, H.H. (1993) Volatile Flavor Components in Snow Crab Cooker Effluent and Effluent Concentrate. Journal of Food Science, 58, 525-530. https://doi.org/10.1111/j.1365-2621.1993.tb04316.x

[56] Liu, H.W., Gai. F., Gasco, L., Brugiapaglia, A., Lussiana, C., Guo, K.J., Tong, J.M. and Zoccarato, I. (2009) Effects of Chestnut Tannins on Carcass Characteristics, Meat Quality, Lipid Oxidation and Fatty Acid Composition of Rabbits. Meat Science, 83, 678-683. https://doi.org/10.1016/j.meatsci.2009.08.003

[57] Linder, M. and Ackman, R.G. (2002) Volatile Compounds Recovered by Solid phase Microextraction from Fresh Adductor Muscle and Total Lipids of Sea Scallop (Placopecten magellanicus) from Georges Bank (Nova Scotia). Journal of Food Science, 67, 2032-2037. https://doi.org/10.1111/j.1365-2621.2002.tb09496.x

[58] Kubota, K., Shijimaya, H. and Kobayashi, A. (1986) Volatile Components of Roasted Shrimp. Agricultural and Biological Chemistry, 50, 2867-2873. https://doi.org/10.1080/00021369.1986.10867836

[59] Bakkali, F., Averbeck, S., Averbeck, D. and Idaomar, M. (2008) Biological Effects of Essential Oils-A Review. Food and Chemical Toxicology, 46, 446-475. https://doi.org/10.1016/j.fct.2007.09.106

[60] Buttery, R.G., Gaudagni, D.G., Ling, L.C., Selfert, R.M. and Lipton, W. (1976) Additional Volatile Components of Cabbage, Broccoli, and Cauliflower. Journal of Agricultural Food Chemistry, 24, 829-832. https://doi.org/10.1021/jf60206a037

[61] Miyasaki, T. and Kitamura, Y. (2012) Suppression of Tilapia Muscle Odor by Seaweed Supplementation to Diet. Aquaculture Science, 60, 349-357. (in Japanese with English Abstract)

[62] Senger-Emonnot, P., Rochard, S., Pellegrin, F., George, G., Fernandez, X. and Lizzani-Cuvelier, L. (2006) Odor Active Aroma Compounds of Sea Fig (Microcosmus sulcatus). Food Chemistry, 97, 465-471.

https://doi.org/10.1016/j.foodchem.2005.05.026

[63] Cruz-Romero, M., Kerry, J.P. and Kelly, A.L. (2008) Changes in the Microbiological and Physicochemical Quality of High-Pressure-Treated Oysters (Crassostrea gigas) during Chilled Storage. Food Control, 19, 1139-1147. https://doi.org/10.1016/j.foodcont.2007.12.004

[64] Agatsuma, Y. (1998) Aquaculture of the Sea Urchin (Strongylocentrotus nudus) Transplanted from Coralline Flats in Hokkaido, Japan. Journal of Shellfish Research, 17, 1541-1547.

[65] Iida, H., Nakamura, K. and Tokunaga, T. (1985) Dimethyl Sulfide and Dimethyl- $\beta$-Propiothetin in Sea Algae. Bulletin of the Japanese Society of Scientific Fisheries, 51, 1145-1150. (In Japanese with English Abstract) 
https://doi.org/10.2331/suisan.51.1145

[66] Suyama, M., Hirano, T. and Yamazaki, S. (1985) Odor of Ayu and Its Volatile Components. Nippon Suisan Gakkaishi, 51, 287-294.

https://doi.org/10.2331/suisan.51.287 